\title{
Drinking Water Quality in the Sagarmatha National Park, Nepal
}

\author{
Kirsten Nicholson', Emily Hayes', Klaus Neumann1, Carolyn Dowling1, Subodh Sharma ${ }^{2}$ \\ ${ }^{1}$ Department of Geological Sciences, Ball State University, Muncie, USA \\ ${ }^{2}$ Department of Environmental Science \& Engineering, Kathmandu University, Dhulikhel, Nepal \\ Email:knichols@bsu.edu
}

Received 7 March 2016; accepted 19 April 2016; published 22 April 2016

Copyright (C 2016 by authors and Scientific Research Publishing Inc.

This work is licensed under the Creative Commons Attribution International License (CC BY). http://creativecommons.org/licenses/by/4.0/

(c) (i) Open Access

\section{Abstract}

In 2014 we began the first systematic study of water quality, specifically fecal contamination of drinking water in the Khumbu Valley, Sagarmatha National Park (SNP, Mt. Everest region), Nepal. Our goal was to identify coliform bacteria and $E$. coli in drinking water and groundwater-fed springs to generate a data set that will function as a base for potable water supplies and further monitoring. Sampling occurred in May (pre-monsoon summer) and early November (post-monsoon early winter) 2014. Sample sites were selected based on proximity to villages and primary use as a drinking water source. Overall, the data presented a predictable correlation between fecal contamination and both elevation and increasing population/tourist traffic. Drinking water within the study area met current World Health Organization drinking water standards for the physical properties of temperature $\left(2.8^{\circ} \mathrm{C}-13^{\circ} \mathrm{C}\right)$, $\mathrm{pH}(5.27-7.24)$, conductivity $(14.5-133 \mu \mathrm{S})$ and $\mathrm{TDS}$ $(7.24-65.5 \mathrm{ppm})$. Samples from the more populated, lower altitude areas had higher levels of $E$. coli. Samples collected and analyzed in May (pre-monsoon summer) had a higher level of $E$. coli and coliform bacteria than samples collected in November (post-monsoon early winter) suggesting a seasonal dependence overlaid on the population signature. Surface water typically had higher $E$. coli values than groundwater-fed springs. Temperature, total dissolved solids and conductivity generally decreased with increasing elevation, whereas $\mathrm{pH}$ increased with increasing elevation. There appears to be significant presence of fecal contamination of water sources due to a combination of tourism, elevation and seasons.

\section{Keywords}

Fecal Coliform, E. coli, Mt. Everest, Drinking Water

\section{Introduction}

The Sagarmatha National Park (SNP; Figure 1) is located in the southeastern part of the Nepali Himalaya on the

How to cite this paper: Nicholson, K., Hayes, E., Neumann, K., Dowling, C. and Sharma, S. (2016) Drinking Water Quality in the Sagarmatha National Park, Nepal. Journal of Geoscience and Environment Protection, 4, 43-53.

http://dx.doi.org/10.4236/gep.2016.44007 


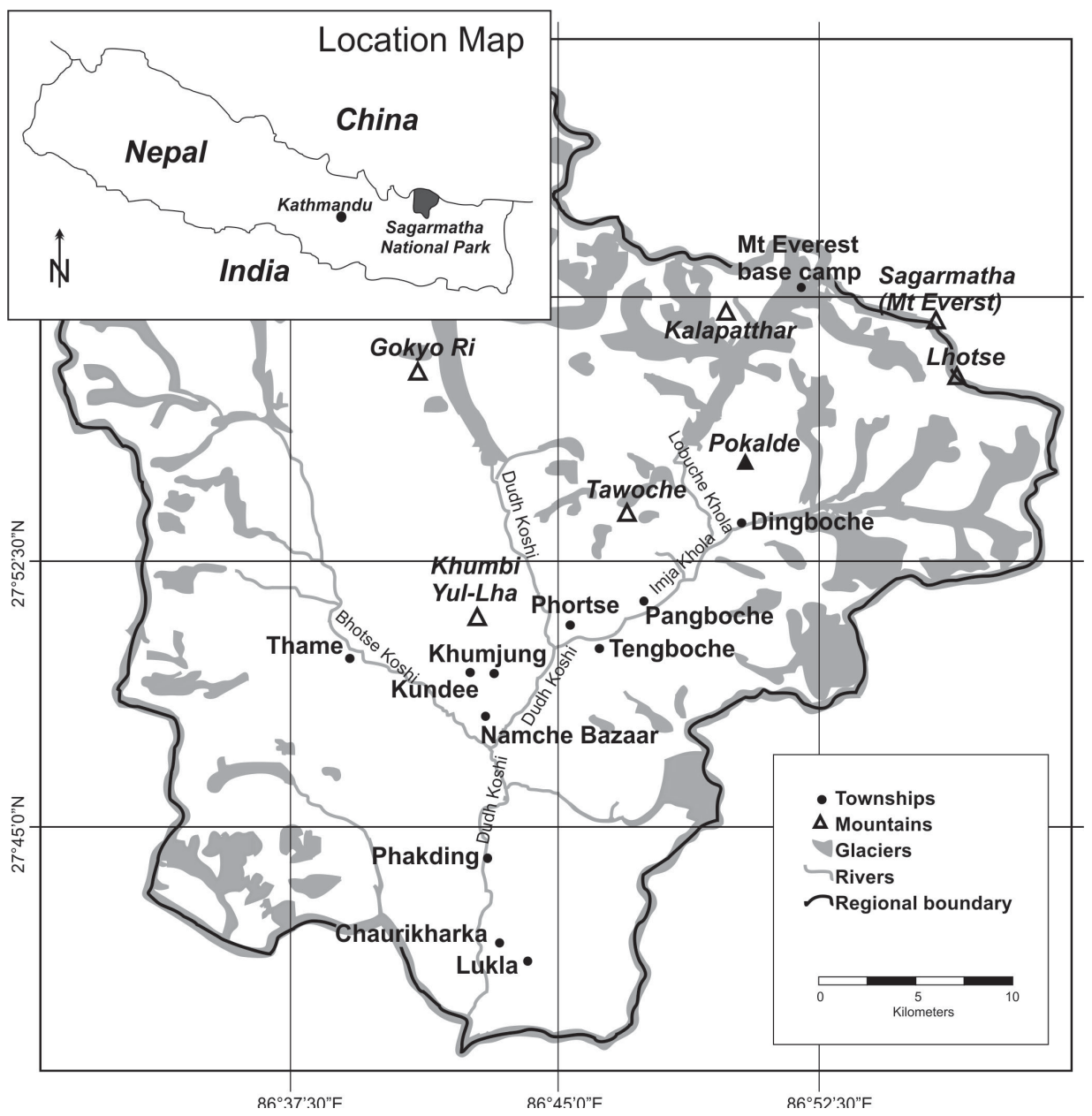

Figure 1. Generalized map showing the major rivers, ice fields, major townships and main mountain peaks, including Mt. Everest. Inset map shows the position of the study area within the country of Nepal.

southern slope of Sagarmatha (Mt. Everest). The SNP is in the Solukhumbu district, approximately $140 \mathrm{~km}$ due east of Kathmandu and covers $1148 \mathrm{sq} \mathrm{km}$. It ranges between $27^{\circ} 30^{\prime} 19^{\prime \prime} \mathrm{N}$ to $27^{\circ} 06^{\prime} 45^{\prime \prime} \mathrm{N}$ latitude to $86^{\circ} 30^{\prime} 53^{\prime \prime} \mathrm{E}$ to $86^{\circ} 99^{\prime} 08^{\prime \prime} \mathrm{E}$ longitude. The elevation of townships and communities in the SNP watersheds varies from 2610 $\mathrm{m}$ (Phakding) to over $5000 \mathrm{~m}$ at Mt. Everest base camp (EBC). The area experiences a temperate climate characterized by cold winters, warm summers and clear seasonality, with average annual precipitation ranging from $450 \mathrm{~mm}$ at EBC to $1800 \mathrm{~mm}$ at Lukla township (the town where tourists begin their trekking adventures). Maximum rainfall generally coincides with the Indian Monsoon, between June and September, and there is great variability of temperature, which ranges from $37^{\circ} \mathrm{C}$ in summer to $-17^{\circ} \mathrm{C}$ in winter. The Himalayan Mountains are the source of water for over a billion people and form the main headwaters for major river systems, such as the Ganges, Yangtze and Indus Rivers [1].

The SNP was established in 1976. It was declared a World Natural Heritage Site in 1979, and is the world's highest altitude protected area. The natural beauty and diversity in culture, flora and fauna, and the majesty of Mt. Everest make it a prime destination for adventure loving tourists [2]. Since the first ascent of Everest in 1953, around half a million trekkers have visited the SNP. The annual number of tourists in the Khumbu region was 20 in 1964, and rose to peak number 32,123 in 2009. In addition to international trekkers, a large number of people visit the SNP as porters and guides [3]. Many protected areas, such as the SNP, have promoted tourism development to improve their economic conditions [3] [4]. However, the negative effects of tourism are of significant concern and tourism operations in protected areas need to be carefully planned, managed and monitored to ensure their long-term sustainability [4]. 
Over the past twenty years, the continuously increasing number of tourists to the SNP is causing increasing anthropogenic pressure with serious environmental consequences to the unique SNP ecosystem [5] [6]. Although the impact is visible primarily along the more popular trekking routes, where non-biodegradable solid wastes (such as water bottles, batteries and more) has resulted in environmental pollution, the effects are also felt in the waterways. Unmanaged or poorly managed solid waste disposal and open defecation have resulted in contamination of the major rivers [5]. Sewage waste is often directly discharged into nearby streams and rivers [7] resulting in considerable degradation of major rivers in the region [5]. Even though the surface water is polluted, it is still used as a potable water supply. However, no studies of local surface water and groundwater and their suitability as reliable water sources have ever been conducted. The SNP is a well suited location to investigate surface and ground water or the effects of tourism on potable water supplies because there is access to moderate and high altitude springs that have and have not been affected by major human populations, which allows for comparative analyses. In addition, the SNP region is generally better studied than other parts of the Himalayan region in terms of geology, glaciology, and anthropology.

In natural systems, microorganisms are widely distributed whereby their diversity and abundances may be used as an indicator for suitable water sources [8]. Although there is a wide range of pathogenic microorganisms that can be transmitted to humans via water contaminated with fecal material (i.e. enteropathogenic agents such as salmonellas, shigellas, enteroviruses, and multicellular parasites as well as opportunistic pathogens like Pseudomonas aeroginosa, Klebsiella, Vibrio parahaemolyticus and Aeromonashydrophila [9]), the isolation and identification of these organisms is extremely complicated and seldom quantitative [10] [11]. As it is not practical to test water for all these organisms, the measurement of $E$. coli and coliform bacteria (total coliform bacteria and/or fecal coliforms) may be used as an indirect approach based on the assumption that the groups of normal enteric organisms will indicate the level of fecal contamination of the water supply [11]-[15]. The presence of coliform bacteria can be used as an indicator of potential danger to human health, as fecal contamination poses significant health risks. Finally, when combined with other indicators such as the physical characteristics of the water as well as distribution and access to water, the presence of bacteria can be used to help identify the reasons behind the contamination.

The study area begins just outside of the SNP boundary at the township of Lukla and extends through to the township of Deboche along the main trekking route to Mt. Everest base camp. It is mainly confined to the DudhKhosi drainage basin (Figure 2). The area is characterized by rugged topography, with altitudes ranging

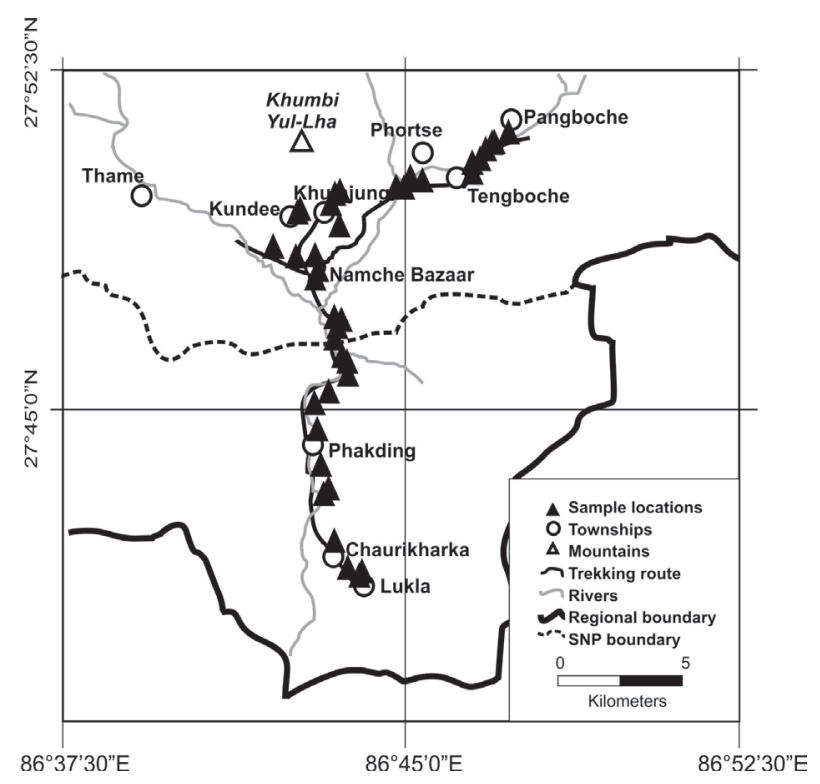

Figure 2. Map of the field study area including the major townships and sample locations (solid triangles). Sample locations correspond to data shown in Table 1 . The dashed line indicates the park boundary with the SNP to the north and the buffer zone in the south. 
Table 1. Data table showing all sample locations from May and October/November 2014.

\begin{tabular}{|c|c|c|c|c|c|}
\hline Date & Sample \# & Northing & Easting & Altitude (m) & Source \\
\hline \multirow[t]{4}{*}{$5 / 8 / 14$} & MAY 1 & 27.42264 & 086.43132 & 2702 & spring fed \\
\hline & MAY 2 & 27.71835 & 086.71604 & 2563 & surface water \\
\hline & MAY 3 & 27.73057 & 086.71380 & 2607 & surface water \\
\hline & MAY 4 & 27.73230 & 086.71326 & 2615 & spring fed \\
\hline \multirow[t]{8}{*}{$5 / 9 / 14$} & MAY 5 & 27.75193 & 086.71057 & 2602 & surface water \\
\hline & MAY 6 & $\mathrm{n} / \mathrm{a}$ & $\mathrm{n} / \mathrm{a}$ & 2650 & surface water \\
\hline & MAY 7 & 27.75913 & 086.71003 & 2700 & surface water \\
\hline & MAY 8 & 27.76195 & 086.71467 & 2700 & surface water \\
\hline & MAY 9 & 27.76969 & 086.72402 & 2800 & surface water \\
\hline & MAY 10 & 27.78205 & 086.72275 & 2810 & surface water \\
\hline & MAY 11 & 27.78375 & 086.72253 & 2843 & surface water \\
\hline & MAY 12 & 27.78550 & 086.72172 & 2850 & surface water \\
\hline \multirow[t]{7}{*}{$5 / 10 / 14$} & MAY 13 & 27.79960 & 086.71024 & 3350 & spring fed \\
\hline & MAY 14 & 27.80255 & 086.71085 & 3440 & spring fed \\
\hline & MAY 14 & 27.80255 & 86.71085 & 3440 & spring fed \\
\hline & MAY 14 & 27.80255 & 086.71085 & 3440 & spring fed \\
\hline & MAY 15 & 27.81528 & 86.7179 & 3440 & surface water \\
\hline & MAY 15 & 27.81528 & 086.71790 & 3440 & surface water \\
\hline & MAY 16 & 27.80636 & 086.70947 & 3440 & spring fed \\
\hline \multirow[t]{3}{*}{$10 / 31 / 14$} & OCT 1 & 27.78202 & 086.72281 & 2810 & surface water \\
\hline & OCT 2 & 27.78549 & 086.72177 & 2843 & surface water \\
\hline & OCT 3 & 27.79905 & 086.71065 & 3370 & surface water \\
\hline \multirow[t]{8}{*}{$11 / 1 / 14$} & NOV 4 & 27.81167 & 086.69595 & 3546 & surface water \\
\hline & NOV 5 & 27.80806 & 086.70241 & 3586 & spring fed \\
\hline & NOV 6 & 27.80634 & 086.70947 & 3512 & spring fed \\
\hline & NOV 7 & 27.80413 & 086.71030 & 3426 & surface water \\
\hline & NOV 8 & 27.81528 & 086.71790 & 3440 & spring fed \\
\hline & NOV 9 & 27.81528 & 086.71790 & 3440 & spring fed \\
\hline & NOV 10 & 27.80255 & 086.71085 & 3440 & spring fed \\
\hline & NOV 11 & 27.80255 & 086.71085 & 3440 & spring fed \\
\hline \multirow[t]{2}{*}{$11 / 2 / 14$} & NOV 12 & 27.84580 & 086.77763 & 3466 & surface water \\
\hline & NOV 13 & 27.83992 & 086.77145 & 3728 & spring fed \\
\hline \multirow[t]{6}{*}{$11 / 3 / 14$} & NOV 14 & 27.83969 & 086.77020 & 3762 & spring fed \\
\hline & NOV 15 & 27.83662 & 086.76598 & 3842 & spring fed \\
\hline & NOV 16 & 27.83558 & 086.76459 & 3864 & spring fed \\
\hline & NOV 17 & 27.83558 & 086.76459 & 3864 & spring fed \\
\hline & NOV 18 & 27.83511 & 086.76278 & 3812 & spring fed \\
\hline & NOV 19 & 27.83216 & 086.74734 & 3852 & spring fed \\
\hline
\end{tabular}




\begin{tabular}{|c|c|c|c|c|c|}
\hline \multicolumn{6}{|l|}{ Continued } \\
\hline & NOV 20 & 27.83233 & 086.74473 & 3891 & surface water \\
\hline & NOV 21 & 27.82983 & 086.73985 & 3444 & spring fed \\
\hline & NOV 22 & 27.82897 & 086.73801 & 3482 & spring fed \\
\hline & NOV 23 & 27.82503 & 086.73041 & 3521 & spring fed \\
\hline & NOV 24 & 27.82569 & 086.71862 & 3,660 & spring fed \\
\hline & NOV 25 & 27.82509 & 086.71645 & 3,764 & spring fed \\
\hline & NOV 26 & 27.82368 & 086.70473 & 3870 & spring fed \\
\hline & NOV 27 & 27.82291 & 086.70359 & 3886 & spring fed \\
\hline & NOV 28 & 27.82082 & 086.71576 & 3,891 & spring fed \\
\hline \multirow[t]{9}{*}{$11 / 5 / 14$} & NOV 29 & 27.77805 & 086.72196 & 2815 & spring fed \\
\hline & NOV 30 & 27.77330 & 086.72262 & 2870 & spring fed \\
\hline & NOV 31 & 27.76991 & 086.72401 & 2908 & surface water \\
\hline & NOV 32 & 27.76742 & 086.72296 & 2896 & spring fed \\
\hline & NOV 33 & $\mathrm{n} / \mathrm{a}$ & $\mathrm{n} / \mathrm{a}$ & & surface water \\
\hline & NOV 34 & 27.75175 & 086.71042 & 2688 & spring fed \\
\hline & NOV 35 & 27.73960 & 086.71194 & 2,610 & spring fed \\
\hline & NOV 36 & 27.73231 & 086.71326 & 2,610 & spring fed \\
\hline & NOV 37 & 27.68955 & 086.72945 & 2,849 & spring fed \\
\hline $11 / 6 / 14$ & NOV 38 & 27.68955 & 086.72945 & 2,860 & spring fed \\
\hline
\end{tabular}

"n/a" means that no data was collected.

from of $2610 \mathrm{~m}$ at Phakding and $2774 \mathrm{~m}$ at Lukla airstrip, to a maximum altitude of $5364 \mathrm{~m}$ at Mt Everest base camp (the lowest Mt Everest base camp). Within the study area there are four main villages: Lukla, Namche Bazaar, Khumjung and Chaurikharka. The four villages are located in this lower portion of the SNP that experiences the highest numbers of tourists each year. It is at risk from the conflicting interests between the need for economic growth (based on tourism) and the ability of the current infrastructure to handle issues such as human waste disposal [3]. The goal of this study was to characterize and monitor potable water quality close to and within the SNP using E. coli and coliform bacteria as indicators of fecal contamination.

\section{Methods}

Water samples were collected in May and November 2014 (Table 1). Sites were selected based on the availability of the water that the local populations and tourist use as drinking. Sample sites include standpipes (water that is brought via tubing from higher elevations), groundwater-fed springs, creeks, and tributary streams. The major rivers and streams were omitted as they previously have been studied in detail [5].

Temperature, $\mathrm{pH}$, conductivity and TDS were measured in the field using a FisherSci Ap85 pH/conductivity meter. Samples taken for bacteria analyses were collected in sterile $100 \mathrm{~mL}$ Whirl-pak bags containing a non-nutritive pill with $10 \mathrm{mg}$ sodium thiosulfate and kept at temperatures below $20^{\circ} \mathrm{C}$ prior to analyses. Analysis of fecal coliform in surface and drinking water followed the EPA approved method 9222D in Standard Methods [16] by using a standard Hach ${ }^{\circledR}$ portable water test kit. Samples were filtered using a hand vacuum pump to filter sample through sterile 0.45 micron filter, placed into a petri dish treated with Hach ${ }^{\circledR}$ m-ColiBlue24® broth medium and placed in a Hach ${ }^{\circledR}$ portable field incubator at $35^{\circ} \mathrm{C} \pm 0.5^{\circ} \mathrm{C}$ for 24 hours. Sample counts were done using a magnifying glass and a $10 \times$ geological hand lens where $E$. coli colonies are royal blue and coliform bacteria colonies appear to be crimson red. Two people counted bacteria samples and duplicate samples were run on approximately every tenth sample. 


\section{Results}

Samples were taken from 27 different localities in May and November 2014 (Figure 2). Of these samples, 17 were from standpipes or groundwater-fed springs and 10 were from minor creeks or tributaries. Where possible, samples were taken from local drinking water sources.

\subsection{Temperature}

Temperatures ranged between $2.8^{\circ} \mathrm{C}$ and $13^{\circ} \mathrm{C}$ with an average of $9.63( \pm 2.6)^{\circ} \mathrm{C}$ (Figure 3(a)). The samples collected in May were on average $2.06^{\circ} \mathrm{C}$ warmer than the samples collected in November. The samples in May ranged between $7.2^{\circ} \mathrm{C}$ and $12.9^{\circ} \mathrm{C}$ with an average of $11.04( \pm 1.5)^{\circ} \mathrm{C}$, whereas the samples collected in November ranged between $2.8^{\circ} \mathrm{C}$ and $13^{\circ} \mathrm{C}$ with an average of $8.96( \pm 2.7)^{\circ} \mathrm{C}$. It includes the November sample from Tengboche (lowest temperature recorded of $2.8^{\circ} \mathrm{C}$ ) that was taken at $8 \mathrm{AM}$ when the air temperature was approximately $-5^{\circ} \mathrm{C}$. This sample was from shallow, slowly moving water, and the air temperature obviously affected the sample. In general, it was noted in the field that air temperature had little effect on groundwater but could have a major effect on slow moving surface waters. However, with this sample removed the November

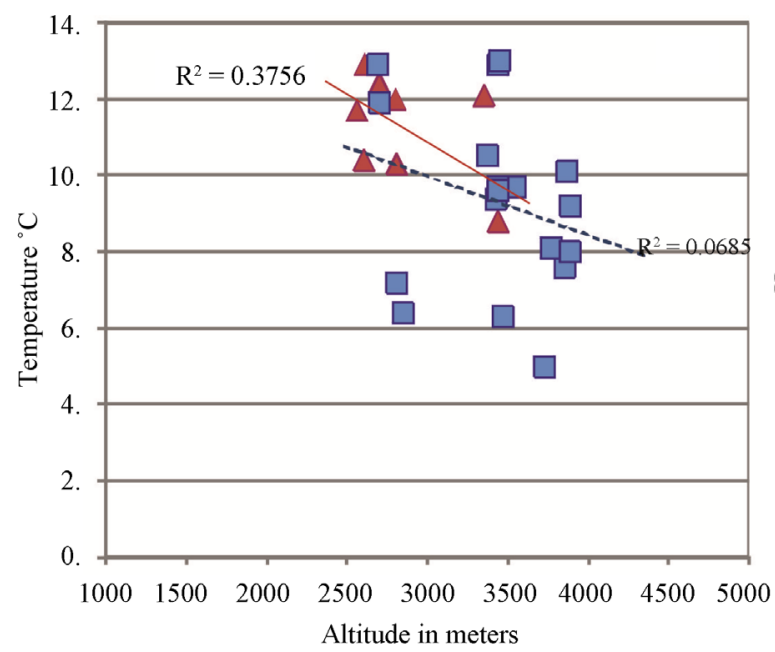

(a)

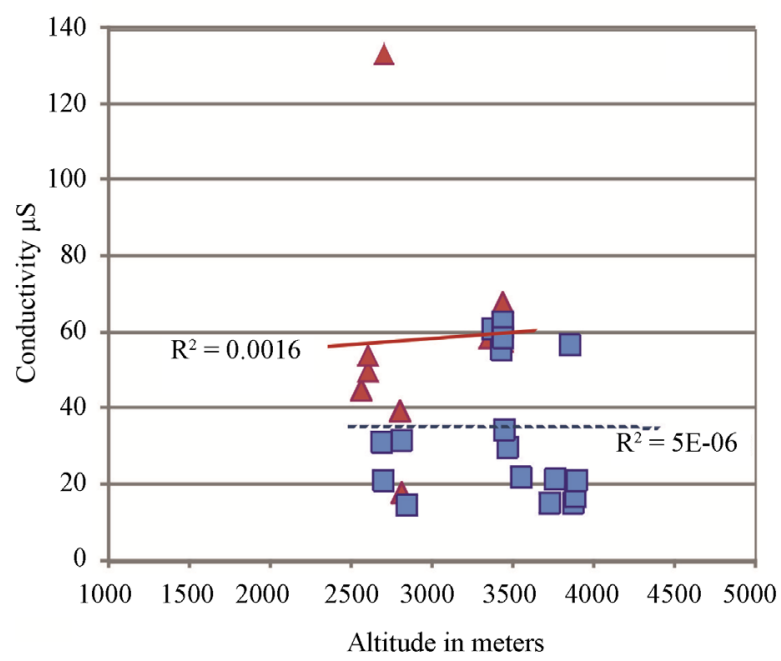

(c)

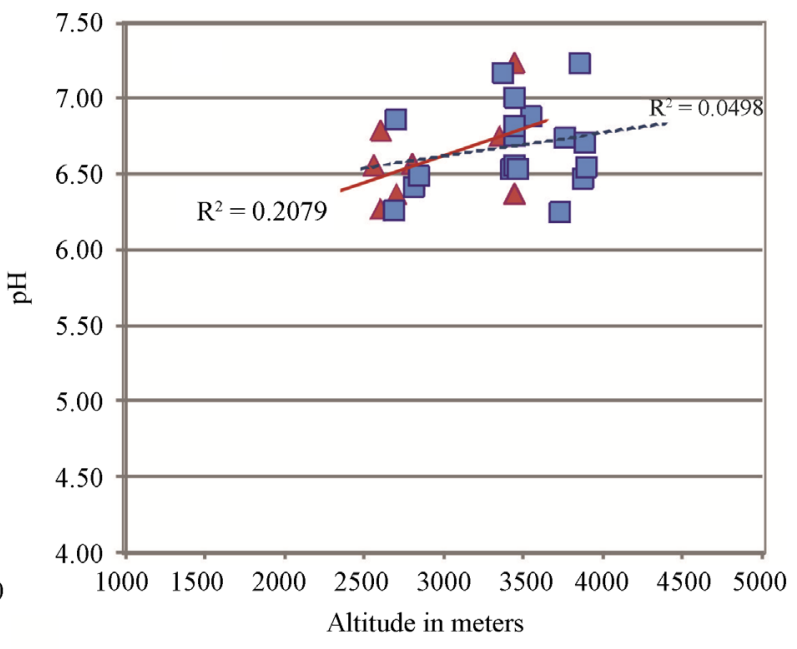

(b)

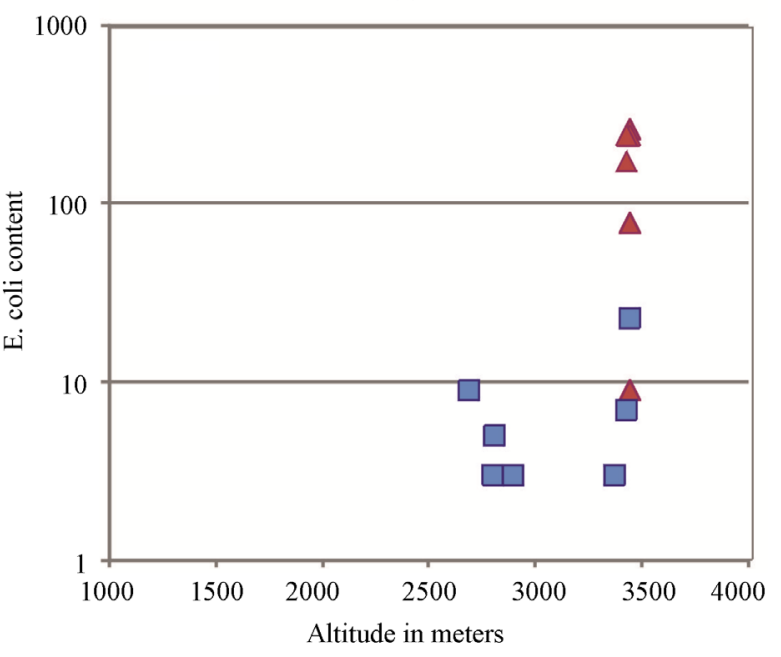

(d)

Figure 3. Bivariate plots showing the relationship between (a) temperature and altitude, (b) $\mathrm{pH}$ and altitude, (c) conductivity and altitude and (d) E. coli and altitude. Red triangles and corresponding red regression lines: May samples. Blue squares and corresponding dashed blue regression lines: November. 
temperature data changes slightly with an increased average temperature of $9.3( \pm 2.4)^{\circ} \mathrm{C}$. As expected, the temperatures decreased with altitude. With the exception of the Tengboche sample, both sets of our data compare well to Ghimire et al. [5] who analyzed 51 sample locations on the four major rivers (DudhKoshi, ImjaKhola, BhoteKoshi, LobucheKhola (Figure 1)) within the SNP that showed an average temperatures varying between $8^{\circ} \mathrm{C}$ and $13^{\circ} \mathrm{C}$, with an average of $10.7( \pm 1.5)^{\circ} \mathrm{C}$, over three years.

\section{2. $\mathrm{pH}$}

The $\mathrm{pH}$ values ranged between 5.27 and 7.24 with an average of $6.60( \pm 0.4)$ (Figure 3(b)). Again the outlying sample is from Tengboche with a pH of 5.27. Excluding the November Tengboche sample, the samples collected in May had a pH range of 6.27 to 7.24 with an average of $6.61( \pm 0.3)$, whereas the November samples range from 6.25 to 7.23 with an average of $6.68( \pm 0.3)$. The observed $\mathrm{pH}$ values for drinking water are within the permissive limit $\mathrm{pH}(6.5$ - 8.5), as prescribed for the drinking water by the World Health Organization (WHO) [17].

\subsection{TDS and Conductivity}

The range in TDS in the samples is relatively small. The average is $21.27( \pm 12.4) \mathrm{ppm}$, with a range between $7.24 \mathrm{ppm}$ and $65.50 \mathrm{ppm}$. Samples taken in May have a slightly higher average (28.46 $\pm 15.5 \mathrm{ppm})$ than the samples collected in November which average $17.86( \pm 9.3)$ ppm. In the 2011 WHO [17] guidelines for drinking water, it is suggested that drinking water should contain less than $600 \mathrm{mg} / \mathrm{L}$ (which is roughly the same as 600 ppm), hence the drinking water in the SNP falls well within the recommended limit.

Conductivity was measured in the same samples and shows similar trends as TDS. The average value for both sets of data is $43.14( \pm 25.3) \mu \mathrm{S}$. Samples collected in November had lower conductivity with an average of $36.10( \pm 18.8) \mu \mathrm{S}$ whereas the samples collected in May had higher values, ranging between $17.87 \mu \mathrm{S}$ and 133 $\mu \mathrm{S}$ with an average of $57.99( \pm 31.5) \mu \mathrm{S}$ (Figure $3(\mathrm{c})$ ).

Figure 3 indicates that the samples show a negative correlation between altitude and the physical parameter of temperature, a positive correlation between altitude and $\mathrm{pH}$, and a near neutral correlation between altitude and conductivity.

\subsection{E coli and Coliform Bacteria}

A total of 41 samples from 27 locations were analyzed for E. coli and coliform bacteria (Escherichia coli and Streptococcus faecolies, respectively). Analyses were conducted proximal to the sampling sites within 20 hours of collection, with a majority conducted within 8 hours after collection. Only five samples were analyzed in May and the remaining 36 analyses conducted in November, which includes repeat sampling of the 5 location analyzed in May. The average high and low air temperatures, respectively, in Namche Bazaar are: $14^{\circ} \mathrm{C}$ and $4^{\circ} \mathrm{C}$ in May, and $9^{\circ} \mathrm{C}$ and $3^{\circ} \mathrm{C}$ in November. As anticipated, due to lack of daylight hours and colder weather conditions [18], the bacterial content was higher in May than in November. Only one sample, from the main groundwaterfed stream running through Namche Bazaar, tested positive for colonies of both E. coli and coliform bacteria. However, retesting the sample location in November showed only minor E. coli colonies $(<5)$ and no coliform bacteria.

The five samples collected and analyzed in May all tested positive for E. coli with colony numbers ranging between 5 and 260 (Figure 3(d)). Only five out of the 36 November samples tested positive for E. coli (with greater than 3 colonies each, Figure 3(d)). Two of the samples were from Namche Bazaar: the main stream (groundwater sourced) running through town and the water supply for one of the local cafes. Three other samples tested positive for E. coli colonies, and they were collected from lower elevations: a lodge at Chaurikharka, the waterfall at Benkar, and a standpipe in Toktok (elevations between $2680 \mathrm{~m}$ and $2900 \mathrm{~m}$ ). Considering the samples collected in November, there appears to be an inverse correlation between the presence of $E$. coli and altitude, with more E. coli detected in lower altitude townships than at higher elevations. This might be a result of several factors including: higher local population, higher numbers of tourists, higher daytime temperatures, and higher levels of surface water in the some springs.

Overall, the groundwater samples (springs and standpipes) contained fewer bacteria than surface water (streams and creeks). Typically, they have lower temperatures than the surface water samples, suggesting that 
the bacteria content might be related to water temperature. However, springs sampled both in May and November had similar temperatures, such as Namche Bazaar town stream, which had a May temperature of $8.8^{\circ} \mathrm{C}$ and a November temperature of $9.4^{\circ} \mathrm{C}$. In May, the Namche Bazaar town stream had significant E. coli colonies whereas in November there were very few. There is no correlation between groundwater temperature and bacteria content.

In summary, surface water samples were more likely to contain bacteria than the groundwater samples, and water samples collected in May were more likely to contain E. coli than those collected in November. The presence of $E$. coli in the surface and groundwater-fed springs is a concern due to the heavy dependence on these drinking sources for the local communities and tourists.

\section{Discussion}

This project investigated the quality of drinking water through physical field characteristics of the water and bacteria values in an effort to identify areas most at risk from fecal contaminated water. This study was necessary along the route to Mt Everest base camp (and in the SNP) because of the increasing number of tourists and lack of water and sanitation infrastructure. In the last forty years the number of visitors to the park has increased from fewer than 100 tourists per year to over 30,000 foreign tourists per year (not including their Nepalese guides and porters). As a result, the area is suffering from significant environmental degradation [5] [6].

A recent study by Salerno et al. [3] focused on tourist impressions of environmental conditions within the SNP, and their results suggest that visitors to the SNP appear to be satisfied with the current conditions, including water quality, energy use and tourist numbers [3]. Non-biodegradable waste can be seen along the major trekking routes; however, the recent addition of waste collection facilities appears to have helped alleviate this problem. Therefore, tourists do not typically see the disposal and results of biodegradable waste, such as human waste. Salerno et al. [3] suggested that there was room for further growth in tourist numbers; however, they also noted that the current environmental conditions would significantly limit growth and further development, and their research suggested that limiting tourist numbers to fewer than 15,000 would mitigate current environmental concerns [3].

Currently unmanaged and/or poorly managed solid waste disposal and open defecation throughout the SNP have resulted in fecal contamination and degradation of the major rivers [5]. In the major townships, it is possible to observe sewage and toilet waste piped into nearby streams and rivers (authors’ personal observations; [7]). This study measured coliform bacteria (total coliform bacteria and/or fecal coliforms) as an indirect method to identify contamination by fecal material as fecal contamination poses significant health risks [11]-[15].

The first study of E. coli and coliform bacteria in the Sagarmatha National Park was conducted by Ghimire et al. [5] between 2008 and 2010. Their study focused entirely on the major rivers within the park, and they concluded that all of the rivers contained $E$. coli and coliform bacteria, although the upper reaches of most rivers did not. Their results summarized the findings from analyses of forty-five water samples that were collected and analyzed at the Central Department of Botany, Tribuvan University (Kathmandu), at Kunde Hospital in Kunde (in 2010) and in a portable laboratory in a hotel in Namche Bazaar. Total coliforms and E. coli estimations were done following APHA [19] methods.

A study published by Baghel et al. [18] of the Gangetic headwaters, beginning at the Gangotri glacier (Uttarakhand, India) and extending $27 \mathrm{~km}$ downstream produced similar results to this study and Ghimire et al. [5]. That investigation involved 21 sites that were sampled three times each year: the pre-monsoon summer, the monsoon, and the post-monsoon winter. The authors found that bacterial contamination increased from the upper, higher altitude, portion of the study area to the lower altitude stretches of the river [18] as shown here in the SNP. The results of Baghel et al. [18] indicate that the rising development in anthropogenic and socio-cultural activities in the lower stretch was responsible for the increased bacterial contamination. Baghel et al. [18] also found that total coliform and thermotolerant coliforms were at a maximum during summer (followed by monsoon and winter), which the researchers attributed to a larger number of pilgrims and trekkers visiting the area during the summer.

Our results are complimentary to those of Baghel et al. [18], Sood et al. [20] and Ghimirie et al. [5] [6]. In general we found that increasing altitude corresponded to decreasing temperature, and increasing pH, TDS, conductivity, and bacteria (Figure 3). Almost all of the samples collected, both in May and November, are slightly alkaline and the physical properties for all of the samples fall within the WHO [17] guidelines for safe 
drinking water. The bacteria content of our samples was higher in the summer (May). November, the post monsoon early winter season, has a reduced number of daylight hours (approximately 11 hours and 5 minutes daylight average), and colder conditions (average daytime highs approximately $9^{\circ} \mathrm{C}$ ) than the pre-monsoon early summer month of May (approximately 13 hours and 20 minutes daylight, and average daytime highs of approximately $14^{\circ} \mathrm{C}$ ) [1]. The shorter days and cooler temperatures most likely explain why samples collected in November contained fewer bacteria than the samples analyzed in May (the effects of daylight, or lack thereof, on E. coli has long been known [21]). As the samples collected in May contained more E. coli than those collected in November, there may be also a relation between $E$. coli and both air temperature and daylight hours in the SNP and surrounding areas.

The largest low-altitude towns (Lukla, Namche Bazaar, Khumjung and Chaurikharka) have the highest density of tourists and the greatest resident populations. Exact population data is difficult to acquire. The Chaurikharka region (including the townships of Lukla and Chaurikharka) has a population of approximately 2200. The population of Namche Bazaar township is 1600 and the combined populations of Khumjung, Kundee and Tengboche are estimated to be 1800 . Our coliform and E. coli data indicate that fecal contamination of drinking water is related to population, the number of tourists and temperature/daylight hours. These results show that field-based monitoring of physical parameters is not sufficient to assess water contamination in the region.

The results of this study also show two similar, but distinct, trends in the data based solely on altitude, which suggest that the lower altitude samples may be affected by different processes. The lower portion of the study area, between Lukla and Monjo, experiences higher tourist and local traffic and is located within the SNP buffer zone, not the SNP proper itself. The differences in field parameters and bacterial content between the buffer zone and SNP proper may relate to more humans, livestock and deforestation, in addition to altitude and tourist traffic. The higher altitude samples, between Namche Bazaar and Deboche have larger temperature ranges but overall show similar trends as the lower altitude samples. This area is completely within the SNP boundary so the difference might be the result of less deforestation, lower temperatures and/or less human impact. Alternatively, these differing trends might reflect variations in rock types, proximity to structural geology features (faulting), and/or ratios of glacial melt in the groundwater between the upper and lower reaches of the study area. Further work is needed to assess the cause of the different trends.

Fecal pollution indicators, such as E. coli and coliform bacteria, can be used to evaluate the health of aquatic ecosystems and the potential for health effects among individuals within those environments [22]. The presence of such indicator organisms may provide evidence of water-borne problems and direct threats to human and animal health. Our study clearly suggests that there is a significant presence of bacterial indicators of fecal pollution in this study area. This work suggests that groundwater-fed springs may be safer to drink during the cold winter months. However, further work is needed to ascertain the bacteria content of the drinking water during the warmer summer months when bacteria levels are likely to be higher. Importantly, more research is needed to ascertain the ultimate water sources, such as glacial melt, to surface water or the shallow groundwater. The quality and quantity of these sources are likely to change with the current global warming trends and accelerated melting of glacial ice, which could have a significant impact on the potable water in the region. Continued monitoring of microbial contamination in the SNP should be an essential component of the environmental protection strategy in the SNP.

The World Tourism Organization (WTO) states that tourism operations in protected areas need to be carefully managed and monitored to ensure their long-term sustainability. Otherwise, such operations will have negative environmental and cultural consequences, and tourism will contribute to the further deterioration [4]. Although the negative effects of tourism are of significant concern, many protected areas have promoted tourism development to improve their economic conditions, particularly to generate revenue to finance other social and economic development activities and to provide direct income and employment opportunities for the local population [3] [4]. In the SNP there are conflicting interests between the need for economic growth based on tourism and the ability of the current infrastructure to handle issues such as human waste disposal. As such, continued monitoring of water quality, specifically fecal contamination, can be used as a key indicator of the effects of both continued economic growth and climate change.

\section{Conclusions}

Our study shows that: 
1) Drinking water within the SNP region currently meets current WHO [17] drinking water standards for the physical properties of temperature $\left(2.8^{\circ} \mathrm{C}-13^{\circ} \mathrm{C}\right), \mathrm{pH}(5.27-7.24)$, conductivity $(14.50-133 \mu \mathrm{S})$ and $\mathrm{TDS}$ (7.24 - $65.5 \mathrm{ppm})$.

2) Samples collected and analyzed in May (pre-monsoon summer) had a higher level of E. coli and coliform bacteria than samples collects in November (post-monsoon early winter) suggesting a seasonal dependence.

3) Samples from surface water sources have higher concentrations of E. coli and coliform bacteria than groundwater-fed springs.

4) Samples from lower altitude drinking water sources were higher in E. coli and coliform bacteria than samples from higher altitude sources.

5) Field-based measurements of physical parameters, temperature, $\mathrm{pH}$, TDS and conductivity alone are not sufficient to detect or monitor drinking water contamination in the SNP.

\section{Acknowledgements}

The authors would like to thank the following people and organizations for their support: Troy Risk Inc. (Indianapolis), Indiana Geologists, Ball State University, AngNorbu Sherpa (Holiday Namche), AngPema Sherpa (Valley View Khumjung) and the Sagarmatha National Park Service.

\section{References}

[1] Balestrini, R., Polesello, S. and Sacchi, E. (2014) Chemistry and Isotopic Composition of Precipitation and Surface Waters in Khumbu Valley (Nepal Himalaya): N Dynamics of High Elevation Basins. Science of the Total Environment, 485-486, 681-692. http://dx.doi.org/10.1016/j.scitotenv.2014.03.096

[2] Salerno, F., Viviano, G., Thakuri, S., Flury, B., Maskey, R.K., Khanal, S.N., Bhuju, D., Carrer, M., Bhochhibhoya, S., Melis, M.T., Giannino, F., Staiano, A., Carteni, F., Mazzoleni, S., Cogo, A., Sapkota, A., Shrestha, S., Pandey, R.K. and Manfredi, E.C. (2010) Energy, Forest, and Indoor Air Pollution Models for Sagarmatha National Park and Buffer Zone, Nepal: Implementation of a Participatory Modeling Framework. Mountain Research and Development, 30, 113126. http://dx.doi.org/10.1659/mrd-journal-d-10-00027.1

[3] Salerno, F., Viviano, G., Manfredi, E.C., Caroli, P., Thakuri, S. and Tartari, G. (2013) Multiple Carrying Capacities from a Management-Oriented Perspective to Operationalize Sustainable Tourism in Protected Areas. Journal of Environmental Management, 128, 116-125. http://dx.doi.org/10.1016/j.jenvman.2013.04.043

[4] WTO (World Tourism Organization) (2005) Tourism’s Potential as a Sustainable Development Strategy. World Tourism Organization, Madrid.

[5] Ghimirie, N.P., Jha, P.K. and Caravello, G. (2013) Physico-Chemical Parameters of High-Altitude Rivers in the Sagarmatha (Everest) National Park, Nepal. Journal of Water Resource and Protection, 5, 761-767. http://dx.doi.org/10.4236/jwarp.2013.58077

[6] Ghimirie, N.P., Jha, P.K. and Caravello, G. (2013) Water Quality of High-Altitude Lakes in the Sagarmatha (Everest) National Park, Nepal. Journal of Environmental Protection, 4, 22-28. http://dx.doi.org/10.4236/jep.2013.47A003

[7] Caravello, G.U., Boselli, A.M., Bertollo, P. and Baroni, A. (2007) Assessing Ecosystem Health: An Analysis of Tourism Related Change and Impact in Khumbu Valley. International Journal of Ecology, 14, 45-64.

[8] Okpokwasili, G.C. and Akujobi, T.C. (1996) Bacteriological Indicators of Tropical Water Quality. Environmental Toxicology and Water Quality, 11, 77-81.

http://dx.doi.org/10.1002/(SICI)1098-2256(1996)11:2<77::AID-TOX1>3.0.CO;2-5

[9] Hodegkiss, I.J. (1988) Bacteriological Monitoring of Hong Kong Marine Water Quality. Environment International, 14, 495-499. http://dx.doi.org/10.1016/0160-4120(88)90410-2

[10] Cairneross, S., Carruthers, I., Curtis, D., Feachem, R., Bradley, D. and Baldwin, G. (1980) Evaluation for Village Water Supply Planning. Wiley, Chichester, 277.

[11] World Health Organization (WHO) (2008) Guidelines for Drinking Water Quality [Electronic Resource]: Third Edition, Incorporating the First and Second Addenda, Volume 1, Recommendations. World Health Organization, Geneva, 668.

[12] Kistemann, T., Claben, T., Koch, C., Dangendorf, F., Fischeder, R., Gebel, J., Vacata, V. and Exner, M. (2002) Microbial Load of Drinking Water Reservoir Tributaries during Extreme Rainfall and Runoff. Applied and Environmental Microbiology, 68, 2188-2197. http://dx.doi.org/10.1128/AEM.68.5.2188-2197.2002

[13] Pathak, S.P. and Gopal, K. (2001) Rapid Detection of Escherichia coli as an Indicator of Faecal Pollution in Water. Indian Journal of Microbiology, 41, 139-151. 
[14] Harwood, V.J., Brownell, M., Perusek, W. and Whitelock, J.E. (2001) Vancomycin-Resistant Enterococcus sp. Isolated from Waste Water and Chicken Feces in the United States. Applied and Environmental Microbiology, 67, 4930-4933. http://dx.doi.org/10.1128/AEM.67.10.4930-4933.2001

[15] Vaidya, S.Y., Vala, A.K. and Dube, H.C. (2001) Bacterial Indicators of Faecal Pollution and Bhavnagar Coast. Indian Journal of Microbiology, 41, 37-39.

[16] APHA (1998) Standard Method for the Examination of Water and Wastewater, 19th ed. American Public Health Association, Washington DC.

[17] WHO (2011) “Guidelines for Drinking Water Quality” [Electronic Resource]: 4th Edition. World Health Organization, Geneva, 541.

[18] Baghel, V.S., Gopalb, K., Dwivedia, K. and Tripathi, R.D. (2005) Bacterial Indicators of Faecal Contamination of the Gangetic River System Right at Its Source. Ecological Indicators, 5, 49-56. http://dx.doi.org/10.1016/j.ecolind.2004.09.002

[19] American Public Health Association (APHA) (2005) Standard Method for the Examination of Water and Wastewater. 21st Edition, American Public Health Association, Washington DC.

[20] Sood, A., Singh, K.D., Pandey, P. and Sharma, S. (2008) Assessment of Bacterial Indicators and Physicochemical Parameters to Investigate Pollution Status of Gangetic River System of Uttarakhand (India). Ecological Indicators, 8, 709-717. http://dx.doi.org/10.1016/j.ecolind.2008.01.001

[21] Gameson, A.L.H. and Saxon, J.R. (1967) Field Studies on Effect of Daylight on Mortality of Coliform Bacteria. Water Research, 1, 279-295. http://dx.doi.org/10.1016/0043-1354(67)90004-8

[22] McLellan, S.L., Daniels, A.D. and Salmore, A.K. (2001) Clonal Populations of Thermotolerant Enterobacteriaceaes in Recreational Water and Their Potential Interference with Foecal Escherichia coli Counts. Applied and Environmental Microbiology, 67, 4934-4938. http://dx.doi.org/10.1128/AEM.67.10.4934-4938.2001 